\title{
Growing a small firm; experiences and managing difficult processes
}

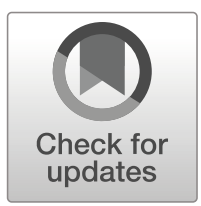

\author{
Maria Tunberg $^{1}$ - Alistair R. Anderson ${ }^{2}$
}

Published online: 21 February 2020

(C) The Author(s) 2020

\begin{abstract}
Contrary to a simple model of small firm growth where increased inputs produce greater outputs, we consider growth is a complex and difficult process. Accordingly, the paper is concerned with how small firms grow, especially how they make sense of the growth process. We collected narratives of the experiences of small firm growth in an extended case study to draw out how growth is understood and managed. We saw how owners became entangled in the process of growing, especially where a change in one aspect led to problems in other dimensions of growth. Their narratives were about trying to make sense, and give some sense to the complexity of growth and some direction to what they should manage. We identified a repertoire of narrative forms: Growth is understood through output indicators, growth is treated as the internal development of the firm and finally, growth is taken to be inevitable - a necessity to which the firm has to conform. These illustrate how growth can be understood as processes of growing, bound up in the context, created in space and time, and contingent on how growth is understood and experienced. Far from a smooth trajectory, enacting growth reflects the experience of the moment, it is shaped by reactions rather than strategy and it is messy rather than ordered. This study contributes to the literature by complementing the functionalist and output oriented view by understanding firm growth as a social phenomenon constructed and reconstructed in the interactions between people and experiences of context.
\end{abstract}

Keywords Firm growth $\cdot$ Small firms $\cdot$ Process $\cdot$ Growing $\cdot$ Narrative $\cdot$ Sensemaking

Maria Tunberg

maria.tunberg@slu.se

Alistair R. Anderson

a.anderson@lancaster.ac.uk

1 Department of Economics, Swedish University of Agricultural Sciences, Box 7013, 750

07 Uppsala, Sweden

2 Lancaster University, Bailrigg, Lancaster, UK 


\section{Introduction}

Small firm growth interests scholars and features strongly in the 'entrepreneurship' literature (Storey 2011). Indeed, growth characteristically informs the ideology of entrepreneurship (Ogbor 2000; Drakopoulou Dodd and Anderson 2007) and small firms (Carland et al. 1984); such that we anticipate growth in small firms (Davidsson et al. 2006). Yet most small firms do not grow and those who do may struggle to maintain growth. Moreover, there is ambiguity about what constitutes 'growth'; increases in jobs, sales or profits? Or is growth about changes in management style, even about a qualitative change in the firm? Hesse and Sternberg (2017) describe growth as non-linear, whilst Giacosa et al. (2018) explain smaller firms differ not only in size from larger firms, but have lower levels of resources. It seems that rather a straightforward natural process, small firm growth is challenging and unusual. We argue that understanding small firm growth is not a trivial or insignificant research problem. Indeed, Liu (2019) argues understanding the nature of entrepreneurial decision-making is essential for entrepreneurship research. Even if knowledge about growth were available, small firm's limited experiences may not offer directions in how best to use the knowledge (Oh et al. 2012; Presutti and Odorici 2019).

For policy makers, firm formation and small firm growth creates new jobs and may add vitality to the economy (Giner et al. 2017; Van Stel and Storey 2004; Haltiwanger et al. 2013; Shane 2009; Coad et al. 2014). For the small firms themselves, growing may be appealing (Apetrei et al. 2019). However, the notably high academic interest in growth (Davidsson and Wiklund 2013; Leitch et al. 2010) has not been matched by increasing numbers of growing firms. Little has changed since Stanworth and Curran (1976) pointed out most small firms don't actually grow." Moreover, although growth is considered a key feature of small firms, much remains unknown about the growth process (McKelvie and Wiklund 2010; Davidsson et al. 2006). Consequently, we are interested in how firms understand and develop capability to manage the growth process. We want to know how small firms try to grow.

Growth is often presented as a natural metaphor. Images of growth frequently propose a small plant, a seedling caringly held in the hand. These demonstrate a simple organic model of growth where growth is the natural state of affairs, simply adding some nutrients the seedling grows into an oak tree (Barringer et al. 2005). As Edith Penrose $(1995 ; 1)$ put it, "akin to a natural biological process". Closely related are the stage models of growth, assuming the firm will grow according to a set of predetermined and clearly distinguishable stages dependent on certain input factors. These views are mirrored in the economic approach to growth (Wach et al. 2018) which is interested in how much a firm has changed over a period of time (Achtenhagen et al. 2010; McKelvie and Wiklund 2010; Delmar et al. 2003). It also infers that inputs (O'Cass and Sok 2014) are the determinants of growth (Davidsson 1991). Furthermore, the importance of high growth firms for job creation (Senderovitz et al. 2016) appears to have led to the search for the Holy Grail of the best mix of inputs to generate growth. It is however now 'evident that the growth process is significantly more challenging and complex than stage models portray' (Macpherson and Holt 2007; 183), and as Storey (2011) points 
out, the factors affecting growth are not easy to capture or model. In fact, evidence suggest that growth is unusual, episodic (Anyadike-Danes et al. 2015) and sometimes traumatic (Anderson and Ullah 2014), even hazardous ( $\mathrm{Ng}$ and Keasey 2010). Firm growth as a growing plant or a stage model may be not only misplaced, but even misleading; small firm growth is not natural, organic nor simple.

The problem we identify is that the actual process of growth, the growing, is often neglected. This is in line with Dutta and Thornhill (2008) noting how few studies reflect what actually happens when firms grow, and McKelvie and Wiklund (2010) proposing that how (rather than the well-established research question of how much) firms grow is the key issue. Our aim is therefore to take a process perspective and explore how firms grow. To address 'growing' as process, we take a social constructionist approach (Fletcher 2004, 2006), believing that growth is likely first understood, made sense of and then enacted (Achtenhagen and Welter 2011; Lindgren and Packendorff 2009). In contrast to perspectives where growth is assumed as universal and unproblematic, the meanings of growth, especially respondents' understandings, take a central place here, informing our research question. How do respondents make sense of growth?

We answer this question through an extended case study of an established small firm trying to grow and experiencing some growth. Our main data are respondents' narratives about growth. Narratives about their experiences offer their reflections on the processes in which they engaged whilst trying to grow. Although these are subjective accounts, they offer grounded practices, rather than theoretical (Mazzei 2018). Moreover, rather than us as researchers imposing our views about growth, the narrative accounts are formed from their lived experiences of the processes. Of course, these may include their biases or even misunderstandings, yet narratives re-present what they experienced in trying to grow.

We found that making sense of growth is problematic, but also identify distinct thematic patterns in the narratives which we categorize as three different sensegiving repertoires. Growth is understood through output indicators; growth is treated as the internal development of the firm and finally, growth is taken to be inevitable, a necessity to which the firm has to conform. Our findings lead us to argue that growth can be understood as the processes of growing. Growing is bound up in the context, created in space and time and is contingent on how growth is understood and experienced. Far from a smooth trajectory, enacting growth reflects the experience of the moment, reactive rather than strategic and messy rather than ordered. We contribute to the literature by complementing the functionalist and output oriented view by understanding firm growth as a socialised phenomenon constructed and reconstructed in the interactions between people and experiences of context. Moreover, our approach engages with the experiences of growing and processes over time, thus avoiding the 'one hit wonders' of rapid but episodic growth. Aside from the theoretical contribution we see a practical contribution in demonstrating that growth is not easy and certainly not a 'natural' outcome. This may better prepare practitioners for growing and also inform policy makers that growth is a complex process. We continue by discussing the problem of small firm growth, we then explain our methods. This is followed by discussion and our conclusions. 


\section{The problem and processes of small firm growth}

Growth has become a buzzword for practitioners, policy makers and scholars, but as Achtenhagen et al. (2010) point out, each have different assumptions. In academia however, firm growth traditionally uses the logic of economics. From a positivistic foundation, firm growth is variously explained and measured by output indicators such as turnover, number of employees and sales figures (Grant and Perren 2002; Delmar et al. 2003) analysing large data sets (Tunberg 2014). The compelling question typically addressed is 'what inputs are needed for growth?' This view reflects only part of Penrose's seminal work on growth. She argued that growth was increases in amounts, but that it was also a firm's internal process of development. This accretion of specific inputs approach has become well established, but the results are somewhat inconclusive. Understanding of the drivers of business growth remains partial and "much remains unexplained" (Wright et al. 2015:4). Moreover, Davidsson et al. $(2010 ; 1)$ similarly noting that knowledge is far from complete, argue that continuing research of this kind is "unlikely to yield much". Moreover, Parry (2010) notes little insight is developed about causality and processes of growth. As we see it, concern with inputs, rate of growth and measurement has crowded out the second part of Penrose's insights; the Penrose effect of managerial limits to growth (O'Farrell and Hitchens 1988). Consequently, much of the growth literature has neglected the processes of growing.

Wright and Stigliani (2013) concluded that growth is a complex construct; it is a longitudinal problem that requires fine grained theorising. They sum up the questions neglected in traditional approaches to growth- how they grow; what decisions are made and in what contexts. In response, and in keeping with broader questions about entrepreneurship (Karataş-Özkan et al. 2014), arguments have been made for adopting different approaches (Leitch et al. 2010; Parry 2010). For example, McKelvie and Wiklund $(2010 ; 271)$ stress understanding how a firm grows, "what goes on within the firm while it is growing". Thus to understand firm growth, social and managerial processes enabling growth could be promisingly investigated (Korsgaard and Anderson 2011). Moreover, interaction between the growing firm and its context better allows for the role played by the external environment (Davidsson et al. 2006; Delmar et al. 2003) and changes over time (Hamilton 2012).

A strength of academic accounts such as the economic perspective on growth, is that they 'objectify' the topic by standing back from the phenomenon and observing general features. In contrast, business owners closely engage with growth, so their views may generate different insights. Achtenhagen et al. (2010) had asked how practitioners make sense of firm growth and concluded that examining the process of growth is more useful and appropriate than merely considering outputs. They found practitioners understood the multidimensionality of growth. Brenner and Schimke (2015) had concluded that growth is often informal, situational and disjointed. We believe that the current state of the art in small firm growth suggests that growth is complex and multidimensional. Growing is more than adding inputs. Macpherson and Holt (2007) describe the situated, complex and idiosyncratic nature of small firm growth; growth is complex process involving what people do, how they do it and of course, how they understand it. In such a view, understanding of the phenomenon of growth is actually 'constructed' rather than 
knowledge sitting on a shelf. For us, this suggests treating small firm growth as a social construction should offer some insights.

\section{Firm growth as a socially constructed phenomena}

Underpinning the approach of social construction, meanings about phenomena like small firm growth are subjectively created, rather than some objective truth available "out there" (Berger and Luckman 1967). Lindgren and Packendorff $(2009 ; 28)$ are concerned that entrepreneurship in positivistic approaches is depicted as "a logical mechanism in society that are caused by some variables and affecting others, thereby severely reducing the complexity of society and the economy.... Likewise, entrepreneurs and their social interactions are reduced into simplistic models". They suggest social constructionism as a complementary paradigm that implies that entrepreneurship is constructed in social interaction between individuals. Moreover, as Radu and Redien-Collot (2008) suggest, social constructions tell people how things are and how they ought to be. In other words, they provide a cognitive framework. Furthermore, Cope (2005) explains meanings are contextually and temporally situated. In this way a social constructionist view of the world is able to use 'meanings' to tap into how things are understood and how they are practiced. We borrow from Perren and Grant $(2000 ; 366)$, growth "is understood as a social construct by individuals interacting" and are interested in how they make and give sense to the phenomenon. Parry $(2010 ; 380)$ explains from the social constructionist viewpoint, meaning is seen to be the product of the subjective experience of the owner-manager and their interrelations with others (Gergen 1999). The ownermanager can be seen as constructing a story about reality using their interpretations of business activities and other 'facts' as they find them.

Building on this notion of social constructing, Parkinson et al. (2016) point out how practices are established through talk, which Watson (2013) describes as discursive practices. The narratives that people use may offer sense making of growth, yet also describe how these perceptions of growth are enacted, sense giving (Toledano and Anderson 2017). In other words, they will relate their 'story' of the process as their experiences. Smith (2017) explains how narratives can contain descriptions of challenges, choices made and outcomes experienced. For us, importantly, they do so in the light of the respondents' experiences. Parry (2010) proposed and first used this approach to explore the relationship between such narratives and small business growth. Accordingly, a social constructions approach that collects narratives responds to Chalmers and Shaw's (2017) insistence that attention must be reoriented towards practice and practical knowledge, with its implications for understanding the how of growing. Hence, in studying firm growth as a social construction, attention is directed to the unfolding of growth processes. "Social constructionism is thus about pluralism in entrepreneurship research; it acknowledges different meanings about entrepreneurship, provides knowledge about interaction processes and describes complexity" (Lindgren and Packendorff 2009; 28). This seems particularly useful when we consider growth as a process of becoming, focusing on "how" and "why" research questions aimed at creating understanding. 


\section{Methods}

Our research design employed a case study (Perren and Ram 2004) informed by social constructionist methods (Downing 2005). The study took 30 months as we interviewed stakeholders, attended meetings and observed practices. We followed Blackburn and Kovalainen (2009) exhortation to avoid 'one-week ethnographies' and generally 'hung around' the small firm. Theoretically, ours was a phenomenological approach employing narratives (Downing 2005; Down 2006) and observation. Our curiosity led us want to know what went on when a firm tried to grow and our bias steered us towards visualizing the process as socially constructing growth. Our rational was that collecting data about how our respondents described growth; their understandings, their practices and of course their objectives, would allow us understand growth from their perspectives. Moreover, familiarity with these methods gave us some confidence that we could establish how growing developed in our case firm. The reasoning for our approach was the calls, for example Leitch et al. (2010), for interpretivist studies to complement the more typical positivistic work on growth.

\section{Data gathering}

We selected this small rural firm which cultivated, packed and sold vegetables because it appeared an interesting and accessible case. It was trying to grow, had grown in some years, but was struggling to maintain growth. This is a purposeful or theoretical sample (Neergaard 2007); selected on the basis that the sample has the qualities in which we are interested- attempting to grow. This sampling method enables researchers to use their judgement to select respondents whose experiences address the research questions (Anderson and Jack 2002). Over time, we developed rapport and deep access as the respondents came to share our interest. We felt it important to contextualize these narrative data within our broader observations, to help explain why they saw things as they did. We collected stories about the respondents' experiences (Watson 2009) and draw on Lincoln and Guba 's (1985) arguments to support the credibility of our analysis. First, we had a long engagement with the company, so came to 'know it'. Moreover, they 'knew us' and supported our enquiry and became genuinely interested in the problem. We shared our views and analysis with them, inviting comments. They rarely challenged what we had to say, but tended to discuss what we found. It seem that our study became a reflective platform for growth. Within the case, our principal respondents, listed in Table 1, were managerial staff. We interviewed these respondents several times, always at the factory.

The case firm, Greenpak is a Swedish farm and processing plant, owned and managed by Marna who inherited the firm from her parents 30 years ago. The focus has always been on growing, processing and selling vegetables. The firm currently employs more than 40 people, including a handful of white collars, the others work on the production lines or in the fields. Since Marna took over in 1997, the firm has grown from 28 employees to 43 in 2015, peaking at 55 in 2006; turnover of approximately 26,000 krona in 1997 grew to approximately 131,000 18 years later (Table 2). As Table 3 shows, growth in the firm has been erratic and episodic; growth appears to vary depending on what indicator and what time period that is chosen. 
Table 1 Respondents within the case study

\begin{tabular}{ll}
\hline Name (anonymized) & Position \\
\hline Marna & Founder and CEO \\
Sam & Senior employee/Unit head \\
Martin & Senior employee/Unit head \\
Stina & Senior employee/Controller \\
Karin & Consultant \\
Hanna & Unit head \\
\hline
\end{tabular}

Moreover, we wanted to set the respondents' narratives in context (Shaw et al. 2017). Because firms grow within an environment and are constrained or enabled by the conditions prevailing in this context (Autio et al. 2014), we wanted to understand this environment. We tackled this by interviewing some 'outsiders', CEO's and/or founders of three neighboring firms operating in the same sector and region and two regional development officials. We interviewed the respondents in Table 3 once.

\section{Data analysis}

The recorded and transcribed data (interviews and field notes) was managed using the qualitative data software tool NVivo. Our primary interest was in the case company, Greenpak respondents' narratives, but as embedded in the wider context of the sector. We studied the data asking, 'What is going on here; what are they telling us?' Described formally, this was the constant comparative method (Glaser and Strauss 1967; Alvesson and Sköldberg 2000; Silverman 2000) of an iterative reviewing of the data with emerging categories and concepts. It involved (Jack et al. 2010) comparing and contrasting patterns of activities to determine categories. Supported by the NVivo software the data was sorted and resorted after each reading until distinctive narratives were identified. This offered a way to 'undertake empirical research which is informed by prior theoretical understanding, but which is not so determined or constrained by this understanding that the potential for making novel insights is foregone' (Finch 2002: 57).

Narratives afford an opportunity to examine meanings embedded in context (Sonenshein 2010) and also show the construction of meaning. As Corner et al.

Table 2 A selection of financial indicators in Greenpak. 1997-2015

\begin{tabular}{llllllll}
\hline & 1997 & 2000 & 2003 & 2006 & 2009 & 2012 & 2015 \\
\hline Turnover* & 26,911 & 35,313 & 63,608 & 103,025 & 120,575 & 110,968 & 131,503 \\
Profit* & -77 & 3098 & 895 & 3537 & -3280 & -3933 & -3388 \\
Equity ratio & $8,3 \%$ & $17,8 \%$ & $11,5 \%$ & $20,4 \%$ & $21,8 \%$ & $14,2 \%$ & $9,73 \%$ \\
Employees & 28 & 31 & 46 & 55 & 50 & 45 & 43 \\
\hline
\end{tabular}

*Numbers in thousand Swedish Crowns. Current exchange rate is approx. $10.5 \mathrm{SEK}=1$ Euro 
Table 3 Respondents outside the firm in the case study

\begin{tabular}{llll}
\hline Interviewee & Type of organization & Name of organization & Position \\
\hline Dan & Municipality & Sim Harbor & Responsible for developing local industry \\
Debra & Municipality & Toms Town & Responsible for developing local industry \\
Sarah \& Jim & Firm & Poultry Meat & Founders \\
Richard & Firm & Poultry Meat & CEO \\
John & Firm & Meadow Farm & Founder and CEO \\
Peter & Firm & The Cider House & CEO \\
\hline
\end{tabular}

(2017) explain, narratives can capture processes as events unfold in time. Our narratives were not the complete stories with a beginning, middle and end that form what Labov (1972) terms 'classic' narratives. Our narratives are what Georgakopoulou (2006) calls 'narratives in interaction'; short-range narratives that give an account of events. We follow Dean and Ford's (2017) argument that whilst business success is broadly characterised as growth, there must also be space for narratives that explore the fluidities of subjectivities and experiences. Narratives can reveal the complexities of entrepreneurs' engagements with circumstances (Corner et al. 2017).

We collected a considerable volume of data; fortunately, it was quickly evident that a strong narrative theme was how our respondents grappled to understand growth. Gioia and Chittipeddi (1991) proposed narratives have sensemaking ability; offering interpretative frameworks; a way of making sense of the world. Sensemaking 'fitted' because our respondents clearly recognised that growth was not straightforward and their experiences of growing did not match the simple model of increasing inputs.

\section{Research findings; categorization of the narratives}

The data clearly show different sensemaking and sense giving narratives. We first present the contextualizing narrative, gathered from interviews outside of the case firm, and then focus on the narratives apparent in the data from the case study. The narratives present the problem of making sense of growth; drawing out how there is confusion about the processes of growing, yet also show how sensegiving narratives (Smith 2017) are used to explain and justify what they do. We found three distinct themes among the sensegiving narratives and label these sensegiving repertoires.

\section{Contextualising the narratives}

The purpose of interviewing 'outsiders' was to inform us about issues that were more generally important, rather than only in the case firm. A powerful theme was the economic necessity to grow, "You can't be too small, it's not possible, it's too much pressure on the price, you will be eaten alive, you won't survive" (Peter, CEO The Cider House). Growth, both in terms of triumphs and problems, was here typically referred to 
in quantitative terms, "it's a two digit grow rate right now" (Richard, CEO Poultry Meat), and, "its constantly red numbers" (Peter, CEO The Cider House). However, an interesting contrast became apparent. Two of the CEOs were not founders, but professionals with business degrees and they talked exclusively about growth as increased outputs. Yet Sarah, who had founded the firm Poultry Meat with her husband Jim, explained "When I left the firm, they decreased the number of products because they started to calculate in purely economic terms- this product is not profitable". Clearly growth and profitability may not be aligned, yet not growing may also reduce profitability. Paradoxically reducing the range of products, shrinking rather than growing, can improve profitability. It became very apparent that relationships between inputs, outputs and profit are understood to be complex.

The process of growing also seemed complex. For example. Peter, the CEO of The Cider House, talked about the tensions between their brand and its association with "genuine craft, family, and locally producing", and expansion. Others talked about choices, "being a family owned firm with a strong focus on developing the local society is not easily incorporated in the logic of more traditional output oriented economic growth" (John, CEO Meadow Farm). An interesting point was raised about the rate of growth, highlighting how the pace of growth was hard to manage, "While a large customer provided great possibilities to grow the firm, it also created demands difficult for the firm to deliver on" (Richard, CEO Poultry Meat). Yet Peter at The Cider House told us, "We have to do it this way: build a little and then get some money, then we build a little".

Whilst growing was seen as complex, we heard three consistent themes in the growth talk; Balancing objectives; Problems associated with growing and an assumption that Growth was always necessary.

Although the output oriented view on firm growth (Grant and Perren 2002; Delmar et al. 2003) was evident, the data provide so much more nuances of growth aligning our study with those portraying growth as a multifaceted process (Leitch et al. 2010), far from the step by step models so widely spread (Levie and Lichtenstein 2010). It was also evident that different types of firm managers related to growth in different ways, adding yet another level of nuance to Achtenhagen et al.'s (2010) study showing the difference in how various types of stakeholders understand growth. The local rural context was seen as a good place to operate, but largely for social reasons which is in line with findings of the advantages of operating in a rural setting (Gaddefors and Anderson 2017). However, as previously described by Gaddefors and Anderson (2019) it also caused problems in that a limited pool of labour was available for growth along with a sense of local responsibility. These data helped us to better understand 'growth' in our case. They provided indicators about the perceived complexity of growth and difficulties in managing process. Moreover, they reminded us about the pressure to grow, even if growth is not a primary objective.

\section{Narrative for sensemaking}

Sensemaking narratives recognised growing as a complex process and the interconnectedness of elements in the process, here exemplified by Marna (CEO Greenpak). The simple growth model jarred with her experience. Growing was a complex problem. 
As Marna put it, "I found it really difficult." In these sensemaking narratives, problems associated with the unpredictability of growth and managing growing surfaced. Growing was challenging because of the complexity and relationships between parts of the process. For example, growth was experienced as unpredictable and not conducive to planning (Anderson and Atkins 2002). In practice, the experience was that you cannot plan, "you could not say today it's perfect, today I'll harvest because then came a hail storm and then it was not perfect at all anymore". Even when growth has been achieved- "it would have been fun to be able to say 'look, we have planned this', that's how it should be", but the experience was rather different, "The customers say one thing and want another and then you suddenly find yourself in a position which you didn't expect". We were told about securing a large new contract, "It is a good contract, but we sold too cheap, and too much at once." Achieving one element of growth (sales) apparently created problems in other areas (production), "They had asked for two trucks and then they took five."

All this seems very different from a simple model of incremental growth which have become well-established both within and outside of academia (Levie and Lichtenstein 2010). Indeed, there is a sense of bewilderment in the experiencing of growth, why is their experience so different from what others appear to do? "how large firms can grow global, I just don't get it...... What kind of super humans are working there?" Even, "Oh my God what do the others do". But growing was experienced not only as serendipity, "we had some exports all of a sudden and that is really fun"; but also as a developing process over time, "with some luck you can build on this, if you have a satisfied customer then you can say 'do you want us to produce for you next year as well? Moreover, growing itself created other problems, 'and it is all the time 'I can sell more, I can sell more!'..... 'we can't produce' and then you have to start dealing with the production and trying to find funding for that".

Underpinning this uncertainty is a thread that it is them who are wrong, that the difficulties experienced in growing are because they don't know what they should know, "Well, it felt like I didn't know anything, there were no truths..." There is an assumption that there is a right way of growing, but they don't know it, "It should be forbidden to start a firm without a business degree". Uncertainty was experienced in a lack of confidence about how to grow, "........ and the union said one thing, and the bank said another, and Rotary has some opinion, and everyone had their opinions on what you did." This sense making problem contrasts received wisdom of growth in the organic metaphor and the encountered reality of growing. Moreover, as well as the earlier comments wondering how others mange, we were told, "I don't have business training, I should have had that." The struggle to make sense was most evident in a trenchant comment, "I don't understand, how do you build, how do you do, what is it that... how do you grow?"

\section{Narratives for sensegiving}

Narratives can also be employed for giving sense. Smith (2017) recently explained how some narratives show purpose and justify actions. Like all narratives, they do this by connecting events with broader frames of reference, but they also generate and give meaning to actions. Thus, we can understand how sensegiving narratives are employed 
to justify and explain, both for themselves and for others. We found the sensegiving data was characterised by three distinctive themes. To reflect the patterns, we labeled these 'repertoires'; "recurrently used systems of terms for characterizing and evaluating actions, events, or other phenomena" (Potter and Wetherell 1987, p149). We describe them as repertoires because they seem to represent a stock of narratives performed to justify and explain how they grow (Steyaert 2007). The repertoire concept has been used to identify recurring patterns in entrepreneurial narratives. Steyaert and Dey (2010) use repertoires to study narratives of social entrepreneurship, Parkinson et al. (2016) apply repertoires to understand the role of context, Braches and Elliott (2017) identify different repertoires in studying the gendered careers of German women, whilst Parry (2010) discuss barriers to growth in artisanal firms with the help of the repertoire concept.

In our data we identify three sensegiving repertoires (Table 4); Growth as a necessity, Growth as a process, and Growth as output. Note however, that these are not mutually exclusive categories, and although they are here discussed as three distinct repertoires, the edges are by no means clear-cut.

\section{Repertoire 1. Growth as necessity}

This first sensegiving justification repertoire helps explain a puzzle- if growth is so difficult, why do they bother? The repertoire justifies growth as an inevitable response to shifting circumstances; growth is a logical response. Stories are told about experiencing changing environments and a resulting need for the firm to change, linking to studies highlighting the role of the context in the growth of a firm (Davidsson et al. 2006; Delmar et al. 2003) Growth, although imperfectly understood, is a required

Table 4 Sensegiving repertoires

\begin{tabular}{|c|c|c|c|}
\hline $\begin{array}{l}\text { Growing } \\
\text { Repertoires }\end{array}$ & Growth as a necessity & Growth as a process & Growth as output \\
\hline Main terms & $\begin{array}{l}\text { Necessary to survive, } \\
\text { Inevitable, unintended } \\
\text { consequences }\end{array}$ & $\begin{array}{l}\text { Financing, Networking, } \\
\text { Organizing, } \\
\text { Constructing, } \\
\text { Developing products }\end{array}$ & Volume, Money \\
\hline Focus & $\begin{array}{l}\text { Firm growth as an } \\
\text { undesirable but an } \\
\text { inescapable part of } \\
\text { running a firm. }\end{array}$ & $\begin{array}{l}\text { Processes of internal } \\
\text { development. }\end{array}$ & The quantitative output as firm growth. \\
\hline Aim & Survival & $\begin{array}{l}\text { Developing the firm, } \\
\text { creating value in the } \\
\text { firm }\end{array}$ & Meeting expectations and requirements \\
\hline Drivers & $\begin{array}{l}\text { External actors such as } \\
\text { customers or } \\
\text { competitors }\end{array}$ & $\begin{array}{l}\text { Internal actors such as } \\
\text { employees, manager }\end{array}$ & $\begin{array}{l}\text { External actors such as consultants, } \\
\text { banks }\end{array}$ \\
\hline $\begin{array}{l}\text { Impact on } \\
\text { the firm }\end{array}$ & $\begin{array}{l}\text { Promotes making } \\
\text { decisions which are not } \\
\text { as planned or intended }\end{array}$ & $\begin{array}{l}\text { Promotes new ideas and } \\
\text { projects }\end{array}$ & $\begin{array}{l}\text { Promotes an increase in concerns about } \\
\text { quantifiable measuring; such as } \\
\text { number of employees, turn over, and } \\
\text { sales figures. }\end{array}$ \\
\hline
\end{tabular}


response to encountered changes. This combines with a perceived obligation to grow, offering sensegiving logic for growing, including managing the trauma and problems that may stem from growing (Anderson and Ullah 2014; Ng and Keasey 2010).

A prominent strand was that growth was necessary to survive; rather than a conscious decision or a strategic development. Described as something outside their control, the language is imperative, loaded with terms such as "must" and "have to". Respondents painted growth as inevitable, but as a survival strategy rather than for the appeal of growing, "If we had not grown we would probably not exist today" (Peter, CEO The Cider House), or simply," we had to grow to survive". Not growing was considered impossible, "If you want to stay in the game you have to invest in more capacity" (Richard), or "You can't be too small, .... you will be eaten alive, you won't survive" (Peter).

A second strand was about the inevitability of growth for responding to competition, "you can never scale down" (Richard) and "growth is absolutely necessary in order to divide the overhead costs". We were told, "You have to have growth" (Peter). Even more telling was a sense of getting caught up, entangled, in growing, "We are stuck in growth by volume and it's easy to quickly end up there" (Marna). This was explained by machinery investments for productivity leading to increased production. Similarly, unintended growth stemmed from fulfilling customers' demands, "We could not produce what the customers expected anymore.... decision to make a large investment" (Peter). Consequently the firm grew, almost involuntarily, from its increased production capacity. A related point was about economies of scale, "We need a CEO, a production manager, a market manager, regardless of if we have a turnover of 100 million or half a billion" (Peter).

\section{Repertoire 2. Growth as a complex process}

The central theme in this repertoire is the complexity of growth (Brenner and Schimke 2015; Wright and Stigliani 2013; Macpherson and Holt 2007); the interconnectedness of different aspects of growing. "If we increase this we must increase that (Peter). Changes in one aspect lead to a chain reaction, a need to make other changes. Some changes are physical, "We built this so that we can build that" (Richard). The point is about the repercussions arising from growing one aspect;

"ok, now we have too few animals, then we need to expand - we need more stables and so we built that, then the issue was that the slaughterhouse couldn't accept that many animals so we had to expand the slaughterhouse, and so we did, and then the issue was that we didn't have enough fridge space so we had to expand the fridges... and then the staff didn't have time to butcher, so we had to hire more staff, and then we had staff that they didn't have any space to sit ... so we had to extend the lunchroom. That's how it was - all the time" (Jim).

This illustrates the processual aspects of growth where, rather than a linear and strategically planned growth process, growth is portrayed as an endless range of connected decisions and actions following on from each other. This is expressed by Brenner and Schimke (2015) as informal, situational and disjointed kind of growth, which becomes difficult to capture or model (Storey 2011) and elusive for pinpointing in research 
(Anderson 2015). This inter connected facets of growth are demonstrated in our cases through funding and networking, practices contributing to the growth of the firm.

Funding of growth is a reoccurring theme in this repertoire; "None of the banks dared to lend us money. Then, at last, we went to the bank located in the same building as our accountant .... and they gave me six million" (Marna), "[sigh] Growth is about trying to get the budget to match". Raising finance was not only about growing, but also an expense caused by growing, "you invest, you know a transformer, environmental investment, those things that have to be done, but that don't give a penny" (Marna). However, not all respondents were negative, (Jim) "We were making a profit. So, we expanded each year". Similarly, "We have to do it this way: build a little and then get some money, then we build a little" (Peter).

Repeatedly we were told about valuable network connections, some international, "So my father went to the US and managed to get into a baby-carrot factory. The people over there tried, and we were friends with a guy there who had a really big factory" (Marna). More local, "I sat next to a retired CEO at a dinner. He was 70 years old and said 'I will help you' and after that he came visiting once a month chairing a fake board meeting with invitation, agenda and everything." (Marna). A point here is that it may be possible to learn about the processes of growing through the experiences of others.

\section{Repertoire 3. Growth as output}

Rather than growing as a process, this repertoire explained growth as result; an end in itself. Growing was repeatedly described in output-based numbers, reflecting the economics of growing. As Marna puts it, "she [the consultant] says more kilos, more kilos. I mean, that is growth to me". Similarly, "The goal for number of visitors is 200 000, and for turnover it's 24 million [krona]" (Peter). Successful growth was financially defined too, "I had a goal that we would grow to half a billion [krona], which we reached - so we are growing vigorously" (Peter,), or "In three years we've increased with almost 60\%" (Peter). "We have grown 100 million [krona] in five years" (Richard).

The focus on financial figures and volume demonstrates growth outcomes. These 'indicators' are easy to communicate and may be used as a shorthand for the complicated phenomenon. However, even then it was tempered by broader issues such as social responsibility, indicating an unease with only financial results. One firm want to contribute to local society, but such an effort was commented by "It is red numbers in such an activity" (Peter). Nonetheless this repertoire worked to signal and justify the desired end point- growth- as a measurable result, aligning with the dominant discourse within firm growth research. Marna explained with a sigh, pointing to sales figures, "This is what firm growth is". For her; crucial but boring, yet a necessary part of running the firm.

\section{Discussion}

In examining practices and processes of growth management, we answered appeals for new perspectives on firm growth (Parry 2010; Wright and Stigliani 2013; Leitch et al. 
2010; Achtenghagen et al. 2010), moving from asking 'how much' a firm grows to asking the more fundamental question of 'how' a firm grows (McKelvie and Wiklund 2010). Considering growth a social construction (Downing 2005), and guided by our research question - How do respondents make sense of firm growth? - we explored practices through studying talk (Parkinson et al. 2016) and found different sensegiving and sensemaking narratives (Jones et al. 2010; Hill and Levenhagen 1995).

We saw how people struggled to understand growth as a phenomena and the processes of how to grow. Like Smith (2017) we could see how the narratives carried descriptions of how the respondents understood and experienced their reality. They made sense of what they did as a complex, often unintended series of interrelated actions and attributed their rationales for growing as necessary reactions to change. This view on growth is very much in line with research such as Macpherson and Holt (2007) arguing that growth is situated, complex and idiosyncratic, Anyadike-Danes et al. (2015) portraying growth as unusual and episodic, or Brenner and Schimke (2015), suggesting growth is informal, situational and disjointed.

Our aim was to explore 'how do firms grow' (McKelvie and Wiklund 2010) but our answer is much less clear. Our results support Wright and Stigliani's (2013) proposal that growth is a complex construct requiring theorizing with great attention to details, or the nuances of the growth process will be lost. A small firm grows through continuity and change, by both response and design. Growth is far from a smooth and linear trajectory as portrayed in the functionalist stage models (Levie and Lichtenstein 2010; Hesse and Sternberg 2017). Rather it is piecemeal and fragmentary; one change engenders other changes and is rarely enacted systematically.

The narratives challenge the conceptual parsimony associated with the concept 'growth', apparently because this neglects the practices of growing. The narratives resonate with complexity, uncertainty and conflicting objectives about how best to achieve the end point of growth itself. Sensemaking draws on received wisdom and experience, perhaps better presented as blending the codified knowledge of growth and the tacit knowledge from experience. Sensegiving narratives applies these rationales to their practices and although they stem from subjective accounts, they offer a grounded perspective on practices, processes and engagement with growth (Mazzei 2018).

Our contribution complements the functionalist and output oriented process view with an understanding of firm growth as a social phenomenon constructed and reconstructed in the interaction between people, their experiences and events. Doing so we add to the small, but growing number of studies analyzing what happens when firms grow (Dutta and Thornhill 2008) and answer requests for focusing on practice and practical knowledge (Chalmers and Shaw 2017). Our finer grained analysis highlights complexity, interaction and uncertainty in change processes. In terms of practical contribution, we provide reassurance for practitioners that their difficulties in growing are not untypical. Moreover, treating growth as an experiential practice highlights the 'discovery' of growth; a paradox of planning for uncertainty. Conceptually, we provide an alternative understanding of firm growth which may better guide policy makers and growth promoters generally. The deterministic and output oriented approach, often portrayed through a linear stage model (Levie and Lichtenstein 2010), is merely one of multiple ways of understanding and experience growth, and acting upon an inadequate, or even misleading, view of how firms grow has several practical implications. It creates false expectations of what it is to be growing and how growth works, which 
may result in managers, investors, and politicians making questionable plans and decisions.

We acknowledge the limitations of our approach; small sample, our interpretation of what we think they mean and of course the context bound nature of our data. As with all interpretative studies, alternative interpretations are possible (Leitch et al. 2010). However, our attention to detailing precisely what our respondents said, coupled with our ability to see these narratives in context gives us confidence in their validity and reliability (Larty and Hamilton 2011) and we hope that we add to understanding small firm growth as a practice.

We propose that future research should be directed towards understanding growth as process rather than merely measuring dimensions of growth. This may involve a move away from positivistic methods towards interpretative approaches (Leitch et al. 2010; Parry 2010; Wright and Stigliani 2013). Moreover, given that most firms don't grow, or grow very much, we suggest the focus should shift from the exceptional high growth to a better understanding of the mundane but more typical examples.

\section{Conclusions}

"There remains the sense that something is missing — something that hinders our ability to gain deeper knowledge of organizational dynamics. That something has to do with understanding the essence of the organizational experience, and perhaps especially the processes".

(Gioia et al. 2013; 16)

Our narratives reflect and enact what Jones et al. (2010) call the strategic space for reflexive learning of sense making. Hill and Levenhagen (1995: 1057) suggest that "to cope with these uncertainties, the entrepreneur must develop a "vision" or mental model of how the environment works (sensemaking) and then be able to communicate to others and gain their support (sensegiving)'. In listening to, and interpreting how, our respondents described their experiences, we hope to have given voice to growth as a difficult process for small firms. In doing so, we also want to highlight the inappropriateness of the 'growth as natural and organic' metaphor. Growing pains seems a better metaphor for how processes were managed.

Open Access This article is licensed under a Creative Commons Attribution 4.0 International License, which permits use, sharing, adaptation, distribution and reproduction in any medium or format, as long as you give appropriate credit to the original author(s) and the source, provide a link to the Creative Commons licence, and indicate if changes were made. The images or other third party material in this article are included in the article's Creative Commons licence, unless indicated otherwise in a credit line to the material. If material is not included in the article's Creative Commons licence and your intended use is not permitted by statutory regulation or exceeds the permitted use, you will need to obtain permission directly from the copyright holder. To view a copy of this licence, visit http://creativecommons.org/licenses/by/4.0/. 


\section{References}

Achtenhagen, L., \& Welter, F. (2011). 'Surfing on the ironing board'-the representation of women's entrepreneurship in German newspapers. Entrepreneurship \& Regional Development, 23(9-10), 763-786.

Achtenhagen, L., Naldi, L., \& Melin, L. (2010). "Business growth"-Do practitioners and scholars really talk about the same thing? Entrepreneurship Theory and Practice, 34(2), 289-316.

Alvesson, M., \& Sköldberg, K. (2000). Reflexive methodology: New vistas for qualitative research. London: SAGE Publications.

Anderson, A. R. (2015). Conceptualising entrepreneurship as economic 'explanation' and the consequent loss of 'understanding'. International Journal of Business and Globalisation, 14(2), 145-157.

Anderson, A. R., \& Atkins, M. H. (2002). Configuration and reconfiguration-planning for uncertainty? International Journal of Entrepreneurship and Innovation Management, 2(4-5), 406-423.

Anderson, A., \& Jack, S. (2002). The articulation of social capital in entrepreneurial networks: A glue or a lubricant? Entrepreneurship and Regional Development, 14(3), 193-210.

Anderson, A., \& Ullah, F. (2014). The condition of smallness: How what it means to be small deters firms from getting bigger. Management Decision, 52(2), 326-349.

Anyadike-Danes, M., Hart, M., \& Du, J. (2015). Firm dynamics and job creation in the United Kingdom: 1998-2013. International Small Business Journal, 33(1), 12-27.

Apetrei, A., Sánchez-García, J. L., \& Sapena, J. (2019). The controversial link between entrepreneurial activity and inequality. International Entrepreneurship and Management Journal, 15(2), 485-502.

Autio, E., Kenney, M., Mustar, P., Siegel, D., \& Wright, M. (2014). Entrepreneurial innovation: The importance of context. Research Policy, 43(7), 1097-1108.

Barringer, B. R., Jones, F. F., \& Neubaum, D. O. (2005). A quantitative content analysis of the characteristics of rapid-growth firms and their founders. Journal of Business Venturing, 20(5), 663-687.

Berger, P., Luckman (1967). The Social Construction of Reality: A treatise on the Sociology of Knowledge.

Blackburn, R., \& Kovalainen, A. (2009). Researching small firms and entrepreneurship: Past, present and future. International Journal of Management Reviews, 11(2), 127-148.

Braches, B., \& Elliott, C. (2017). Articulating the entrepreneurship career: A study of German women entrepreneurs. International Small Business Journal, 35(5), 535-557.

Brenner, T., \& Schimke, A. (2015). Growth development paths of firms-A study of smaller businesses. Journal of Small Business Management, 53, 539-557.

Carland, J. W., Hoy, F., Boulton, W. R., \& Carland, J. A. C. (1984). Differentiating entrepreneurs from small business owners: A conceptualization. Academy of Management Review, 9(2), 354-359.

Chalmers, D. M., \& Shaw, E. (2017). The endogenous construction of entrepreneurial contexts : A practicebased perspective. International Small Business Journal, 35(1), 19-39.

Coad, A., Daunfeldt, S.-O., Hölzl, W., Johansson, D., \& Nightingale, P. (2014). High-growth firms: Introduction to the special section. Industrial and Corporate Change, 23(1), 91-112.

Cope, J. (2005). Researching entrepreneurship through phenomenological inquiry. International Small Business Journal, 23(2), 163-189.

Corner, P. D., Singh, S., \& Pavlovich, K. (2017). Entrepreneurial resilience and venture failure. International Small Business Journal, 35(6), 687-708.

Davidsson, P. (1991). Continued entrepreneurship: Ability, need, and opportunity as determinants of small firm growth. Journal of Business Venturing, 6(6), 405-429.

Davidsson, P. and Wiklund, J. (2013). eds. New perspectives on firm growth. Edward Elgar Publishing.

Davidsson, P., Delmar, F., \& Wiklund, J. (2006). Entrepreneurship and the growth of small firms. Cheltenham: Edward Elgar.

Davidsson, P., Achtenhagen, L., \& Naldi, L. (2010). Small firm growth. Foundations and Trends in Entrepreneurship, 6(2), 69-166.

Dean, H., \& Ford, J. (2017). Discourses of entrepreneurial leadership: Exposing myths and exploring new approaches. International Small Business Journal, 35(2), 178-196.

Delmar, F., Davidsson, P., \& Gartner, W. B. (2003). Arriving at the high-growth firm. Journal of Business Venturing, 18(2), 189-216.

Down, S. (2006). Narratives of enterprise: Crafting entrepreneurial self-identity in a small firm. Cheltenham: Edward Elgar Publishing.

Downing, S. (2005). The social construction of entrepreneurship: Narrative and dramatic processes in the coproduction of organizations and identities. Entrepreneurship Theory and Practice, 29(2), 185-204.

Drakopoulou Dodd, S., \& Anderson, A. R. (2007). Mumpsimus and the mything of the individualistic entrepreneur. International Small Business Journal, 25(4), 341-360. 
Dutta, D. K., \& Thornhill, S. (2008). Evolution and change in entrepreneurial growth intentions: Developing a cognition-based model. Journal of Business Venturing, 23(3), 307-332.

Finch, J. (2002). The role of grounded theory in developing economic theory. Journal of Economic Methodology, 9(2), 213-234.

Fletcher, D. (2004). International entrepreneurship and the small business. Entrepreneurship \& Regional Development, 16(4), 289-305.

Fletcher, D. E. (2006). Entrepreneurial processes and the social construction of opportunity. Entrepreneurship \& Regional Development, 18(5), 421-440.

Gaddefors, J., \& Anderson, A. R. (2017). Entrepreneursheep and context: When entrepreneurship is greater than entrepreneurs. International Journal of Entrepreneurial Behavior and Research, 23(2), 267-278.

Gaddefors, J., \& Anderson, A. R. (2019). Romancing the rural: Reconceptualizing rural entrepreneurship as engagement with context (s). The International Journal of Entrepreneurship and Innovation, 25(3), 159169.

Gergen, K. J. (1999). Invitation to social construction. London: SAGE Publications.

Georgakopoulou, A. (2006). Thinking big with small stories in narrative and identity analysis. Narrative Inquiry, 16(1), 122-130.

Giacosa, E., Mazzoleni, A., \& Usai, A. (2018). Business process management (BPM): How complementary BPM capabilities can build an ambidextrous state in business process activities of family firms. Business Process Management Journal, 24(5), 1145-1162.

Giner, J. M., Santa-María, M. J., \& Fuster, A. (2017). High-growth firms: Does location matter? International Entrepreneurship and Management Journal, 13(1), 75-96.

Gioia, D. A., \& Chittipeddi, K. (1991). Sensemaking and sensegiving in strategic change initiation. Strategic Management Journal, 12, 433-448.

Gioia, D. A., Corley, K. G., \& Hamilton, A. L. (2013). Seeking qualitative rigor in inductive research: Notes on the Gioia methodology. Organizational Research Methods, 16(1), 15-31.

Glaser, B., \& Strauss, A. (1967). The discovery of grounded theory: Strategies for qualitative research. New York: Aldine.

Grant, P., \& Perren, L. (2002). Small business and entrepreneurial research: Meta-theories, paradigms and prejudices. International Small Business Journal, 20(2), 185-211.

Haltiwanger, J., Jarmin, R., \& Miranda, J. (2013). Who creates jobs? Small versus large versus young. The Review of Economics and Statistics, 95(2), 347-361.

Hamilton, R. T. (2012). How firms grow and the influence of size and age. International Small Business Journal, 30(6), 611-621.

Hesse, N., \& Sternberg, R. (2017). Alternative growth patterns of university spin-offs: Why so many remain small? International Entrepreneurship and Management Journal, 13(3), 953-984.

Hill, R. C., \& Levenhagen, M. (1995). Metaphors and mental models: Sensemaking and sensegiving in innovative and entrepreneurial activities. Journal of Management, 21(6), 1057-1074.

Jack, S., Moult, S., Anderson, A.R. and Dodd, S.D, 2010. An entrepreneurial network evolving: Patterns of change. International Small Business Journal, 28(4), pp.315-337.

Jones, C., Livne-Tarandach, R., \& Balachandra, L. (2010). Rhetoric that wins clients: Entrepreneurial firms use of institutional logics when competing for resources. Research in the Sociology of Work, 21, 183-218.

Karataş-Özkan, M., Anderson, A. R., Fayolle, A., et al. (2014). Understanding entrepreneurship: Challenging dominant perspectives and theorizing entrepreneurship through new post positivist epistemologies. Journal of Small Business Management, 52(4), 589-593.

Korsgaard, S., \& Anderson, A. R. (2011). Enacting entrepreneurship as social value creation. International Small Business Journal, 29(2), 135-151.

Labov, W. (1972). Language in the Inner City. Philadelphia: University of Pennsylvania Press.

Larty, J., \& Hamilton, E. (2011). Structural approaches to narrative analysis in entrepreneurship research: Exemplars from two researchers. International Small Business Journal, 29(3), 220-237.

Leitch, C., Hill, F., \& Neergaard, H. (2010). Entrepreneurial and business growth and the quest for a "comprehensive theory": Tilting at windmills? Entrepreneurship Theory and Practice, 34(2), 249-260.

Levie, J., \& Lichtenstein, B. (2010). A terminal assessment of stages theory: Introducing a dynamic states approach to entrepreneurship. Entrepreneurship Theory and Practice, 34(2), 317-350.

Lincoln, Y. S., \& Guba, E. G. (1985). Naturalistic inquiry. Newbury Park: Sage.

Lindgren, M., \& Packendorff, J. (2009). Social constructionism and entrepreneurship: Basic assumptions and consequences for theory and research. International Journal of Entrepreneurial Behavior \& Research, $15(1), 25-47$.

Liu, Y. T. (2019). Exploring the role of original aspiration in effectuation tendency. International Entrepreneurship and Management Journal, 15(3), 977-1016. 
Macpherson, A., \& Holt, R. (2007). Knowledge, learning and small firm growth: A systematic review of the evidence. Research Policy, 36(2), 172-192.

Mazzei, M. J. (2018). Strategic entrepreneurship: Content, process, context, and outcomes. International Entrepreneurship and Management Journal, 14(3), 657-670.

McKelvie, A., \& Wiklund, J. (2010). Advancing firm growth research: A focus on growth mode instead of growth rate. Entrepreneurship Theory and Practice, 34(2), 261-288.

Neergaard, H. (2007). Sampling in entrepreneurial settings. In H. Neergaard \& J. Ulhøi (Eds.), In handbook of qualitative research methods in entrepreneurship (p. 253). Cheltenham: Edward Elgar.

$\mathrm{Ng}$, W., \& Keasey, K. (2010). Growing beyond smallness: How do small, closely controlled firms survive? International Small Business Journal, 28(6), 620-630.

O'Cass, A., \& Sok, P. (2014). The role of intellectual resources, product innovation capability, reputational resources and marketing capability combinations in firm growth. International Small Business Journal, 32(8), 996-1018.

O'Farrell, P. N., \& Hitchens, D. M. (1988). Alternative theories of small-firm growth: A critical review. Environment and Planning A, 20(10), 1365-1383.

Ogbor, J. O. (2000). Mythicizing and reification in entrepreneurial discourse: Ideology-critique of entrepreneurial studies. Journal of Management Studies, 37(5), 605-635.

Oh, K. Y., Anderson, A. R., \& Cruickshank, D. (2012). Perceived barriers towards the use of e-trade processes by Korean SMEs. Business Process Management Journal, 18(1), 43-57.

Parkinson, C., Howorth, C. and Southern, A., (2016). The crafting of an (un) enterprising community: Context and the social practice of talk. International Small Business Journal, 35(4), 385-404.

Parry, S. (2010). Smalltalk: Rhetoric of control as a barrier to growth in artisan micro-firms. International Small Business Journal, 28(4), 378-397.

Penrose, E. (1995). The theory of the growh of the firm. Oxford: Oxford University Press.

Perren, L., \& Grant, P. (2000). The evolution of management accounting routines in small businesses: A social construction perspective. Management Accounting Research, 11(4), 391-411.

Perren, L., \& Ram, M. (2004). Case-study method in small business and entrepreneurial research mapping boundaries and perspectives. International Small Business Journal, 22(1), 83-101.

Potter, J., \& Wetherell, M. (1987). Discourse and social psychology: Beyond attitudes and behaviour. Sage.

Presutti, M., \& Odorici, V. (2019). Linking entrepreneurial and market orientation to the SME's performance growth: The moderating role of entrepreneurial experience and networks. International Entrepreneurship and Management Journal, 15(3), 697-720.

Radu, M., \& Redien-Collot, R. (2008). The social representation of entrepreneurs in the French press desirable and feasible models? International Small Business Journal, 26(3), 259-298.

Senderovitz, M., Klyver, K., \& Steffens, P. (2016). Four years on: Are the gazelles still running? A longitudinal study of firm performance after a period of rapid growth. International Small Business Journal, 34(4), 391-411.

Shane, S. (2009). Why encouraging more people to become entrepreneurs is bad public policy. Small Business Economy, 33, 141-149.

Shaw, E., Wilson, J., \& Pret, T. (2017). The process of embedding a small firm in its industrial context. International Small Business Journal, 35(3), 219-243.

Silverman, D. (2000). Doing qualitative research. London: SAGE Publications.

Smith, R., (2017). Reading liminal and temporal dimensionality in the Baxter family 'public-narrative'. International Small Business Journal, 36(1), 41-59.

Sonenshein, S. (2010). We're changing - Or are we? Untangling the role of progressive, regressive, and stability narratives during strategic change implementation. Academy of Management Journal, 53(3), 477-512.

Stanworth, M. J. K., \& Curran, J. (1976). Growth and the small firm-An alternative view. Journal of Management Studies, 13(2), 95-110.

Steyaert, C. (2007). 'Entrepreneuring'as a conceptual attractor? A review of process theories in 20 years of entrepreneurship studies. Entrepreneurship and Regional Development, 19(6), 453-477.

Steyaert, C., \& Dey, P. (2010). Nine verbs to keep the social entrepreneurship research agenda 'dangerous'. Journal of social entrepreneurship, 1(2), 231-254.

Storey, D. (2011). Optimism and chance: The elephants in the entrepreneurship room. International Small Business Journal, 29(4), 303-321.

Toledano, N. and Anderson, A.R., (2017). Theoretical reflections on narrative in action research. Action Research, p.1476750317748439.

Tunberg, M. (2014). Approaching rural firm growth: A literature review. Journal of Enterprising Communities: People and Places in the Global Economy, 8(4), 261-286. 
Van Stel, A., \& Storey, D. (2004). The link between firm births and job creation: Is there a Upas tree effect? Regional Studies, 38(8), 893-909.

Wach, D., Stephan, U., Marjan, J.G. and Wegge, J., (2018). Entrepreneurs' achieved success: Developing a multi-faceted measure. International Entrepreneurship and Management Journal, on line, pp.1-29.

Watson, T. (2009). Entrepreneurial action, identity work and the use of multiple discursive resources: The case of a rapidly changing family business. International Small Business Journal, 27(3), 251-274.

Watson, T. (2013). Entrepreneurship in action: Bringing together the individual, organizational and institutional dimensions of entrepreneurial action, 2013. Entrepreneurship and Regional Development, 25, 404 422.

Wright, M., \& Stigliani, I. (2013). Entrepreneurship and growth. International Small Business Journal, 31(1), 3-22.

Wright, M., Roper, S., Hart, M., \& Carter, S. (2015). Joining the dots: Building the evidence base for SME growth policy. International Small Business Journal, 33(1), 3-11.

Publisher's note Springer Nature remains neutral with regard to jurisdictional claims in published maps and institutional affiliations. 